\title{
PANDANGAN IBN QUDAMAH TENTANG WAKAF DAN RELEVANSINYA DENGAN WAKAF DI INDONESIA
}

\author{
M. Khoirul Hadi Al-Asy'ari \\ Dosen IAIN Jember \\ E-mail: hadiari701@gmail.com
}

\begin{abstract}
Abtract
This research is based on a research library, which is based on the study of literature, this research theme is taken is endowment in view of Ibn Qudamah and its relevance to the development of waqf in Indonesia, in this paper, there are three important questions first, how the concept of waqf in Ibn Qudamah view, and secondly how sosiohistoris biography of Ibn Qudama? and thirdly how the relevance of the opinion of Ibn Qudama of endowments with the development of waqf in Indonesia?, with the approach of content analysis and historical for mencoa analyze endowments and life history of Ibn Qudama, the results of the research paper is first, knowing the concept of waqf Ibn Qudamah, and the second knowing Ibn Qudamah biography, and relevance of thought waqf Ibn Qudamah with developments in Indonesia.
\end{abstract}

Keywords: Ibn Qudamah, waqf, and relevance.

\section{A. Pendahuluan}

Islam diyakini sebagai agama yang universal, tidak terbatas oleh ruang dan waktu. Al-Qur'an sendiri menyatakan bahwa ajaran Islam berlaku untuk seluruh umat (lihat misalnya: QS. Saba: 38 dan Al-Anbiya: 107). Karena sifatnya yang universal, maka Islam diyakini sebagai agama yang mampu menjawab tantangan di setiap zaman dan tempat. Namun sayangnya, klaim tersebut tidak diikuti dengan aplikasi ijtihad yang memadai di lapangan. Hukum Islam yang dipahami selama ini lebih banyak mengarah pada seperangkat aturan yang merupakan produk ijtihad ulama masa lalu dengan kondisi sosial dan budaya yang mengitarinya. Fikih dianggap sebagai refleksi hukum Tuhan yang tidak dapat dirubah. Tanpa disadari, pemahaman inilah yang justru mengakibatkan sifat fleksibilitas dan keakomodatifan Islam seakan-akan hilang, padahal kalau kembali ke kaidah ' la yungkaru tagayyur al-ahkam bi tagayur al-azminah wa alamkinah wa al-ahwal" (Al-Suyuthi, 1995: 74) akan nampak betapa sangat elastis sebenarnya hukum Islam itu. Implikasinya adalah hukum yang ditetapkan di suatu tempat dan waktu tertentu tidak harus selalu diberlakukan di tempat dan waktu berbeda.

Dalam konteks hukum Islam (Masoed, 1995: 23-29), setelah melalui abad tengah yang cenderung konservatif dan menolak perubahan, maka sejak abad tengah para ahli hukum semakin menyadari bahwa perubahan baik melalui proses reformasi islah maupun pembaharuan (tajdid) adalah sesuatu yang tidak dapat dielakkan (Minhaji, 2002: 187), pembaharuan terhadap persoalan hukum ternyata merambah pada kajian 
hukum keluarga (Anderson, 1959: 2526) dan hukum wakaf dan zakat, sala satu persoalan yang sangat serius adalah dalam bidang wakaf. Wakaf merupakan salah satu tuntutan ajaran Islam yang menyangkut kehidupan bermasyarakat dalam rangka ibadah ijtimā'iyah (ibadah sosial) (Anshori, 2004: 1), karena wakaf adalah bentuk ibadah sosial yang dapat diambil manfaatnya bagi kepentingan orang lain atau manusia pada umumnya, maka benda wakaf harus bersifat kekal zatnya, seperti tanah, bangunan dan lain sebagainya. Prinsip keabadian yang ada pada wakaf itu sehingga banyak ulama yang memandang bahwa wakaf adalah perbuatan shadaqah jariyah yang pahalanya terus mengalir meski waqif telah meninggal, selagi harta itu masih bermanfaat (Praja, 1995: 9). Dalam hadis Nabi yang diriwayatkan Imam Muslim disebutkan:

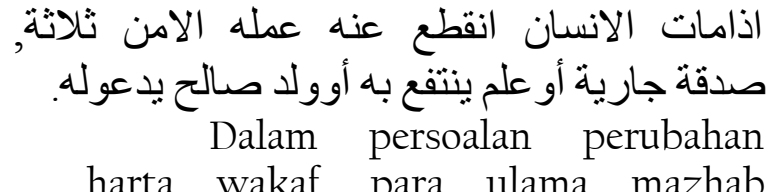
berbeda pendapat dalam menghadapi persoalan ini. Imam As-Syafi'i tidak memperbolehkan perbuatan tersebut baik benda bergerak maupun benda tetap. Sedangkan Hanafiyah dan Malikiyah membolehkan baik benda bergerak maupun benda tetap kecuali masjid. Seorang ulama pengikut Ahmad ibn Hanbal yaitu Ibn Qudamah, membolehkan untuk merubah wakaf, baik benda bergerak maupun benda tetap, baik berupa masjid maupun non masjid. Kebolehan merubah harta wakaf menurut Ibn Qudamah, tidak membatasi jenis wakafnya baik masjid maupun non masjid, wakaf bergerak dan tidak bergerak dan barang pengganti wakaf tersebut berkedudukan sebagai harta wakaf seperti semula (Mughniyah, 2001: 56).

Ibn Qudamah mengatakan bahwa apabila harta wakaf mengalami rusak sehingga tidak dapat memberi manfaat sesuai dengan tujuannya, hendaklah dijual saja, kemudian harga penjualannya dibelikan barang lain yang akan mendatangkan manfaat sesuai dengan tujuan wakaf dan barang yang dibeli itu berkedudukan sebagai harta wakaf seperti semula (Qudamah, 2006: 36). Perwakafan di Indonesia, telah dikenal dan dilaksanakan oleh umat Islam sejak agama Islam masuk di Indonesia. Sebagai suatu lembaga Islam, wakaf telah menjadi salah satu penunjang perkembangan masyarakat Islam. Sebagian besar rumah ibadah, perguruan Islam dan lembaga-lembaga keagamaan Islam lainnya dibangun di atas tanah wakaf (Qahaf, 2005: xv). Namun pengaturan tentang sumber hukum perwakafan di Indonesia, tata cara, prosedur dan praktik perwakafan bisa dibilang baru (Anshori, 2006: v).

Di berbagai negara yang perwakafannya sudah berkembang dengan baik, wakaf merupakan salah satu pilar ekonomi yang dapat dipergunakan untuk meningkatkan kesejahteraan masyarakat. Negara yang sangat berpengalaman dalam mengembangkan wakaf di antaranya adalah Indonesia. Pengelolaannya dilakukan dengan cara menginvestasikan harta wakaf di bank Islam dan berbagai perusahaan. Dengan dikembangkannya wakaf secara produktif, wakaf dapat dijadikan salah satu lembaga yang diandalkan pemerintah untuk mewujudkan kesejahteraan bangsa. Metode 
pembaharuan hukum Islam dapat dikatagorikan kepada beberapa macam, yaitu intra-dokrinal (dengan mengambil dokrin dari manzhab fikih lain), extradokrinal (dengan mengambil unsurungsur di luar hukum Islam sama sekali), regulatori dan kodifikasi (Mahmood, 1972: 267-270). Oleh karena itu, dapat dikatakan bahwa reformasi hukum waris dan wakaf yang ada di Maroko dan Indonesia itu akan menggunakan metode extra-dokrinal reform dan intra-dokrial (dengan mengambil dokrin dari mazhab fikih lain).

Dalam undang-undang wakaf di Indonesia, pada dasarnya harta yang telah diwakafkan dilarang untuk diwariskan, dihibahkan, disita, dijadikan jaminan, dijual, kecuali ditukar. Namun dalam pengecualian ini diatur dalam pasal 41 yaitu:

(1) Ketentuan sebagaimana dimaksud dalam Pasal 40 huruf $f$ dikecualikan apabila harta benda wakaf yang telah diwakafkan digunakan untuk kepentingan umum sesuai dengan rencana umum tata ruang (RUTR) berdasarkan ketentuan peraturan perundang-undangan yang berlaku dan tidak bertentangan dengan syari'ah. (2) Pelaksanaan ketentuan sebagaimana dimaksud pada ayat 1 hanya dapat dilakukan setelah memperoleh izin tertulis dari Menteri atas Persetujuan badan Wakaf Indonesia. (3) Harta benda wakaf yang sudah diubah statusnya karena ketentuan pengecualian sebagaimana dimaksud pada ayat 1 wajib ditukar dengan harta benda yang manfaat dan nilai tukar sekurang-kurangnya sama dengan harta benda wakaf semula. (4) Ketentuan mengenai perubahan status harta benda wakaf sebagaimana dimaksud pada ayat Isampai ayat 3 UU No. 41 Tahun 2004 diatur lebih lanjut dengan Peraturan Pemerintah.

Di Indonesia berbagai pembenahan hukum dilakukan oleh pemerintah, namun benturan yang terjadipun tidak dapat dihindarkan, hukum Islam sebagai hukum yang telah menyatu dengan adat istiadat masyarakat, menjadi hidup (status quo)(Soekanto 1980: 23) di lingkungan masyarakat agraris (masyarakat yang berpusat pada kiyai atau tokoh masyarakat yang didasarkan kharismatik dan ikatan emosional) (Durkheim, 2001: 32). Akibatnya, perundang-undangan yang telah dilegislasi oleh pemerintah sering menimbulkan "kekosongan hukum", konstitusi yang sifatnya mengikat tetapi tidak dapat menyentuh masyarakat agraris (Syamsuddin, 1998: 123). Sebagai contoh dapat kita lihat penelitian yang dilakukan oleh kalangan sarjana seperti nikah sirri, sengketa waris, perwakafan tanah. Ketika terjadi benturan dalam masyarkat, maka mereka cenderung merujuk pada tokoh-tokoh masyarakat, ketika menyelesaikan persoalan rujukannya adalah hukum Islam (fiqh klasik). Terjadinya pengabaian undangundang bukan karena ketidaktahuan mereka pada undang-undang yang telah dibuat, tetapi dilandaskan oleh perasaan normatif yang telah mengakar dalam pikiran mereka, bahwa fiqh adalah aturan yang harus dijalankan karena terkait dengan aturan agama sedangkan undang-undang atau aturan yang telah dilegislasi bukan berdasarkan pada agama, oleh karena itu, tidak harus diikuti (Rasydi, 1996: 23). Hukum wakaf yang sebelumnya hidup di tengah masyarakat dalam 
bentuk fiqh karena berbagai pembenahan hukum yang dilakukan oleh pemerintah, mengalami proses legislasi kemudian menjadi UndangUndang Wakaf No. 4l tahun 2004 seperti yang dikemukakan di atas bahwa hukum yang ada dalam masyarakat setelah mengambil bentuknya sebagai produk undangundang cenderung diabaikan. Hal inilah yang membuat penulis tertarik untuk melakukan penelitian ini, sejauhmana tingkat relevansi pendapat Ibn Qudamah dengan undang-undang wakaf di Indonesia, dengan berbagai perbedaan yang menyertai kedua bentuk hukum tersebut, fiqh sebagai bentuk tradisi hukum Islam yang ditulis dalam berbagai kitab mazhab hukum dalam Islam, sedangkan undang-undang merupakan corak continental. Anggapan bahwa, masyarakat (normatif) mempunyai hubungan yang relasional (relasi teks dan konteks) dengan undang-undang, supaya terlihat jelas bahwa antara undang-undang wakaf dan fiqh (aturan yang hidup dalam masyarakat) mempunyai keterkaitan atau bahkan diadopsi (dengan memakai model takhayyur dan talfiq) (Hooker, 2003: 57) oleh pemerintah demi ketertiban hukum dalam masyarakat. Dalam hal ini, penulis (melakukan pra research) melihat bahwa UndangUndang Wakaf No. 41 tahun 2004 terlihat adanya keterkaitan dengan pendapat Ibn Qudamah, hal tersebut penulis batasi dalam syarat-syarat yang ada pada Undang-Undang Wakaf No. 41 tahun 2004 bahwa di dalam pasal tersebut tidak ditentukan wujud benda wakaf yang harus diganti tetapi berlandaskan maslahat.

Dalam uraian di atas maka menjadi penting utuk dikaji, karena mengangkat tentang tema wakaf dalam pandangan Ibn Qudamah dan relevansinya dengan kajian dan implemetasi wakaf di Indonesia.

\section{B. Biografi Ibnu Qudamah}

Muwaffaquddin Ibn Qudamah al-Maqdisi (w.620 H./1223 M.) adalah syaikhul Islam al-Imam al-Faqih azZahid Muwaffaquddin Abu Muhammad Abdullah bin Muhammad bin Qudamah bin Miqdam bin Nasr bin Abdullah bin Hudzaifah bin Muhammad bin Ya'qubbin Qasim bin Ibrahim bin Isma'il bin Yahya bin Muhammad bin Salim bin Abdullah bin Umar bin al-Khattab ra., al-Adawi alQurasyi al- Jumali al-Maqdisi adDimasyiah-Shalihi. Ibn Qudamah berasal dari keluarga terhormat yang terkenal keilmuan, keutamaan, ketakwaan dan kesalehannya, ia hidup pada masa rentang waktu dari tahun 541 H. sampai tahun 620 H. (Esposito, 2001: 146). Pada rentang waktu tersebut, Bani Abbasiyah dipimpin oleh beberapa khalifah, di antaranya pertama, Al-Muqtafi Billah, Abu Abdillah Muhammad al-Mustazhir Billah. Ia memerintah dari tahun 530 hingga 555 H. Kedua, Al-Mustanjid Billah, Abu Muzhaffar Yusuf bin Muhammad alMuqtafi Billah. Ia memerintah sejak wafatnya ayahnya (tahun 555 H.) sampai tahun 566 H. Ketiga, AlMustadhi' Billah, Abu Muhammad alHasan bin Yusuf al-Mustanjid Billah. Ia memerintah sejak tahun 566 sampai tahun $575 \mathrm{H}$.

Masa-masa tersebut adalah masa yang penuh dengan peristiwa dan pergolakan politik yang merembet sampai sektor sosial, ekonomi dan keilmuan. Rentang waktu tersebut adalah masa berakhirnya Daulah 
Fathimiyyah di Mesir yang awalnya dibangun oleh Mu'iz Lidinillah alFathimi pada tahun 359 H., dan berakhir dengan wafatnya al 'Adhid Abdullah bin Yusuf al-Hafizh Abu Muhammad pada tahun 567 H., selama kurang lebih 208 tahun. Muwaffaquddin Ibn Qudamah pada saat itu berumur 26 tahun. Yaitu memasuki usia dewasa, kehidupan yang paling menentukan, penentuan jati diri dan berkarya bagi seorang pemuda. Di samping itu, ia menyaksikan akhir perang Salib pada masa Shalahuddin alAyyubi yang berhasil mematahkan kekuatan pasukan Salib di Hiththin dan berhasil membebaskan Baitul Maqdis dari cengkraman mereka pada bulan Rajab tahun $583 \mathrm{H}$, setelah mereka menguasainya selama 92 tahun. Rentang waktu tersebut adalah zaman yang penuh dengan tragedi peperangan, pergolakan dan penyimpangan di antara pemimpin Daulah Islamiyah, dan tidak pernah berhenti setelah Baghdad dikuasai oleh tentara Tartar (Mongolia). Ibn Qudamah mengalami semua iklim tersebut, bahkan ia juga terjun ke seluruh kota yang dipimpin oleh para Amir (Gubernur) berada di tengah-tengah para khalifah dan Amir, seperti Shalahuddin al-Ayyubi dan lainlain juga berteman baik dengan Ibn Hubairah yang terkenal alim, wara', zuhud dan adil. Ibn Hubairah adalah seorang Perdana Menteri (wazir) dari tahun 544 sampai 560 H., pada masa pemerintahan al-Muqtafi dan alMustanjid. Al-Muqtafi pernah memujinya dengan mengatakan "Bani Abbasiyah tidak memiliki seorang Perdana Menteri yang seperti dirinya". Selanjutnya Ibn Qudamah berangkat ke Baghdad pada tahun $561 \mathrm{H}$. untuk menuntut ilmu sejak wafatnya Ibn
Hubairah pada tahun itu juga. Para ulama banyak yang mengagumi pengaruh, keilmuan dan kemuliaannya. Pada waktu itu ia berumur 20 tahun, namun motivasinya yang kuat untuk mencari ilmu telah membuahkan hasil. Semua tragedi yang menimpa dunia Islam berupa hancurnya satu pemerintahan dan berdirinya pemerintahan yang baru, dan kemenangan Shalahuddin serta masamasa kaum muslimin dalam kekuasaan tentara salib, telah memberikan andil yang tidak kecil bagi diri Ibn Qudamah.

Demikianlah kehidupan Ibn Qudamah dari sisi politik. Adapun dari sisi keilmuan, ia hidup pada masa keemasan yang dibanjiri oleh para ulama besar yang bukan hanya di Syam namun di seluruh dunia Islam. Ketika seluruh keluarga Abu Abbas menetap di lereng Gunung Qasiyun, mulailah Muwaffaquddin Ibn Qudamah belajar ilmu, menghafal al-Qur'an, menyibukkan diri dalam mencari ilmu dan memperoleh dasar-dasar berbagai cabang ilmu dari ayahnya. Kemudian ia belajar kepada Abul Makarim bin Hilal dan kepada beberapa Syaikh dan ulama Damaskus. Bahkan ia telah menghafal kitab Mukhtasar al-Kharaqiy dalam bidang Fiqh Mazhab Hambali dan kitab-kitab lainnya. Ketekunannya dalam mencari ilmu dan mempelajari ilmu terus berlanjut hingga menginjak usia 20 tahun. Lalu bersama-sama dengan putra bibinya (Abdul Ghani) berangkat ke Baghdad pada tahun 561 $\mathrm{H}$., kemudian bergabung dengam madra>sah Syaikh Abdul Kadir al-Jailani yang waktu itu berusia 90 tahun. Kepada Abdul Kadir al-Jailani, Ibn Qudamah membacakan (untuk diteliti) kitab Mukhtasar al-Kharaqiy dengan ketelitian pemahaman yang mendalam 
karena ia telah menghafalnya sewaktu berada di Damaskus.

Setelah Syaikh Abdul Kadir alJailani wafat, Ibn Qudamah belajar lagi pada sejumlah Syaikh di negeri Baghdad. Di antaranya yang paling terkenal Abul Fath Ibnul Manni (seorang imam mazhab Hambali pada masanya) dan Hitabullah ad-Daqa' (alMaqdisi, 2003: 35), dan lain-lain. Setelah tinggal di Baghdad selama 4 tahun, ia kembali ke Damaskus melewati daerah Mousul, Abul Fadhl, dan tinggal bersamanya selama setahun, pada tahun $574 \mathrm{H}$., menunaikan ibadah haji dan sempat belajar kepada Syaikh al-Hafizh al-Muhaddits Abu Muhammad al-Mubarak bin Ali athThabbak al-Baghdadi, seorang ulama mazhab Hambali yang tinggal di Makkah. Setelah selesai melaksanakan ibadah haji ia kembali ke Baghdad dan belajar kepada Ibn Manni lagi. Ia juga belajar lagi kepada sejumlah Syaikh untuk waktu yang singkat kemudian ia kembali ke Damaskus dan menyembunyikan diri untuk belajar dan menyusun kitab (ta'lif). Karena ketekunannya itu, Ibn Qudamah berhasil menyusun kitab al-Mughni Syarkh Mukhtashar al-Kharaqi, sebuah kitab dalam bidang fiqh. Kitab al-Mughni ini adalah sebuah kitab unggulan yang berhasil mengolaborasi masalahmasalah hukum dengan mendetail. Kitab ini juga merupakan kitab yang paling besar yang disusun dalam bidang Fiqh Islam secara umum dan Fiqh afiliasi mazhab Hambali khususnya. Bahkan ulama besar al-'Izz bin Abdissalam pernah berkata "tidak pernah kulewati masa mudaku melainkan ada kitab al-Mughni di sisiku." Ia tekun belajar disamping menyusun kitab. Ia pelajari berbagai cabang ilmu seperti Fiqh, Hadis dan lain-lain. Banyak pula yang belajar kepadanya, di antaranya adalah putra saudaranya, Syamsuddin Abul Fajar Abdurrahman bin Muhammad bin Ahmad, putra bibinya, Imam Ibrahim bin Abdul Wahid al-Maqdisi yang juga saudara dari Hafizh Abdul Ghani, dan lain-lain. Muwaffaqiddin Ibn Qudamah alMaqdisi termasuk ulama besar di kalangan mazhab Hambali. Ia berafiliasi dengan mazhab ini dalam hal ilmu maupun dirayah. Ia juga termasuk mujtahid. Namun secara global pendapatnya mengikuti mazhab Hambali, dan dalam beberapa hal ia berseberangan dengan mazhab yang dianutnya dan mandiri dengan pendapatnya sendiri. Hal itulah yang menunjukkan bahwa ia juga seorang ulama mujtahid (al-Maqdisi, 2003: 37).

Ia telah menduduki tempat yang tinggi dalam jajaran ahli fiqh mazhab Hambali, dan termasuk ulama sentral dalam mazhabnya. Sebab ia telah mengahafal kitab Masa'il al-Kharaqi pada usia masih belia dan telah menelaah berbagai kitab mazhab Hambali. Bahkan ada yang mengatakan "Ibn Qudamah adalah pembawa bendera mazhab Hambali pada masanya." Ketinggian ilmunya telah membawanya ke jenjang ijtihad pendapatnya yang dituangkan dalam kitabnya telah menjadi semacam 'pengantar' bagi ulama setelahnya (al-Maqdisi, 2003: 45). Salah satu teori yang ditulisnya adalah tentang istidlal.

Secara terminologi, istidlal adalah cara memahami dan menetapkan dalildalil hukum. Dalam kitab figh dasar-dasar Islam TM. Hasbi mendefinisikan alistidlal sebagai "suatu cara menegakkan dalil-dalil agama kepada tiap-tiap 
kejadian berdasarkan empat cara penetapan at-Talazum baina al-Hukmaini, istishabulhal, istihsan dan al-Masalih alMursalah" (Hasbi, 1953: 55). Bagi Hasbi ketika memahami dan menetapkan dalil agama pada suatu masalah ke empat hal tersebut yakni, at-Talazum baina alHukmaini, istishabulhāl, istihsān, al-Mashlah al-Mursalah merupakan patokan dasar yang harus diperhatikan sekaligus sebagai instrumen dan alat analisis ketika memakai metode istidlal. Dalam metode ini at-Talazum baina al-Hukmaini diartikan sebagai kelaziman atau pertalian yang pasti ada di antara dua hukum atau dengan kata lain, suatu rangkaian hukum yang menyebabkan timbulnya rangkaian hukum yang lain. Misalnya hubungan antara hukum tidak adanya wudhu dengan tidak adanya sembahyang, sedangkan istishabulhal berarti menetapkan hukum yang awal dengan tidak merubahnya karena suatu hal yang belum diyakini. Misalnya, ketika seseorang shalat tiba-tiba muncul kekhawatiran dalam hatinya bahwa boleh jadi dia telah mengeluarkan angin yang bisa membatalkan wudhu. Dalam masalah ini maka hukum yang berlaku adalah hukum yang awal dan keraguraguan yang datang belakangan tidak dapat merubah hukum yang semula (Hasbi, 1953: 55).

Sementara istihsān dalam metode ini diartikan sebagai mengembalikan hukum kepada hal-hal yang dapat menjaga kemaslahatan. Dalam hal ini sesuatu hukum yang dari qiyas jali dapat ditinggalkan dan menggantikannya dengan qiyas khafi karena suatu maksud kebaikan dan sesuai dengan hasil penyelidikan yang benar. Instrumen istidlal yang terakhir al-Masalih alMursalah, yatiu memelihara maksud- maksud syara' dengan jalan menolak kerusakan atas mahluk, misalnya dalam sebuah organisasi telah terpilih seorang pemimpin tetapi dalam perjalanannya muncul figur lain yang lebih kompeten untuk memimpin organisasi tersebut. Berdasarkan konsep al-Masalih alMurasalah, maka pemimpin tersebut diberikan kesempatan untuk melanjutkan masa jabatannya agar bisa menghindari kekacauan dalam organisasi tersebut, akibat insiden pergantian pemimpin itu.Berangkat dari ke empat instrumen dan alat analisis dalam metode istidlal ini, tampaknya Hasbi ingin menegaskan bahwa metode-metode istidlal yang dipergunakan harus dibingkai dengan metode Ushul Fiqh yang rasional dan kontekstual. Hal ini membuktikan betapa luasnya pandangan ulama-ulama untuk menegakkan hukum agama bagi segala kejadian dalam masyarakat yang senantiasa berubah-ubah dari zaman ke zaman (Hasbi, 1953: 55). Dalam mazhab-mazhab hukum Islam, dasardasar istidlal ini berbeda-beda. Meski semuanya merujuk pada al-Qur'an dan as-Sunnah sebagai sumber utama istidlal, tetapi terdapat perbedaan dalam prioritas sumber rujukan setelah alQur'an dan as-Sunnah. Jika Mazhab Hanafi menetapkan dasar-dasar istidlalnya pada al-Qur'an dan asSunnah, ra'yi dari khabar ahad, qiyas dan istihsan. Mazhab Maliki menetapkan metode istidlalnya pada al-Qur'an dan as-Sunnah, ijma' Ahl al-Madinah, fatwa sahabat, Khabar Ahad dan Qiyas, alIstihsan, al-Mashlahah al-Mursalah, Sadd alZara'i, Istihsab dan Syar'u Man Vablana Syar'un Lana. Syafi'i pada al-Qur'an dan as-Sunnah, Ijma' dan Qiyas. Maka Mazhab Hambali menetapkan dasar 
istidlalnya pada: pertama, Nash dari alQur'an dan Sunnah yang shahih. Apabila telah mendapati suatu nash dari al-Qur'an dan dari Sunnah Rasul yang shahih, maka penetapan hukum adalah dengan nash itu. Kedua,Fatwa para sahabat Nabi Saw. Apabila tidak mendapatkan suatu nash yang jelas, baik dari al-Qur'an maupun dari hadis shahih, maka menggunakan fatwafatwa dari para sahabat Nabi yang tidak ada perselisihan di kalangan mereka. Ketiga, Para sahabat Nabi yang timbul dalam perselisihan di antara mereka dan diambilnya yang lebih dekat kepada nash al-Qur'an dan as-Sunnah. Apabila tidak menemukan fatwa sahabat yang disepakati, maka mereka menetapkan hukum dengan cara memilih dari fatwafatwa mereka yang dipandang lebih dekat kepada al-Qur'an dan as-Sunnah. Keempat, Hadis mursal dan hadis dha'if. Apabila Ahmad ibn Hanbal tidak menemukan dari al-Qur'an dan asSunnah yang shahih serta fatwa-fatwa sahabat yang disepakati atau diperselisihkan, maka menetapkan hadis mursal dan hadis dha'if. Kelima, Qiyas apabila Ahmad ibn Hanbal tidak mendapatkan nash, baik al-Qur'an dan as-Sunnah yang shahih serta fatwafatwa sahabat, maupun hadis mursal dan dha'if, maka Imam Ahmad ibn Hanbal dalam menetapkan hukum menggunakan qiyas. Kadang-kadang menggunakan al-Masalih al-Mursalah terutama dalam bidang siyasah (Yanggo, 1997:143). Secara spesifik, metode istidlal Ibn Qudamah tidak dapat dilihat secara jelas dan berdiri sendiri. Tetapi sebagai murid Imam Ahmad Ibn Hanbal dan mazhab Hambali, metode istidlal hukum Ibn Qudamah sangat terpengaruh dengan metode istidlal yang dipergunakan oleh Imam Ahmad Ibn Hanbal. Hal ini dapat dilihat dari cara Ibn Qudamah menetapkan hukum-hukum Islam. Seperti cara dia menetapkan hukum perubahan status harta wakaf, Ibn Qudamah menggunakan dalil hadits yang diriwayatkan al-Bukhari sebagai berikut:

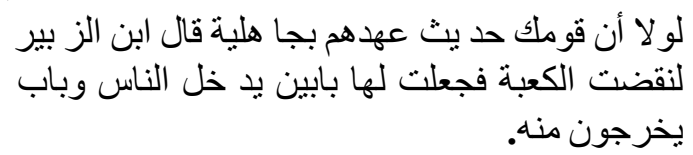

Dari dalil yang dipergunakan oleh Ibn Qudamah di atas, dapat dipahami bahwa metode argumentasi Ibn Qudamah didasarkan pada logika berpikir yang rasional. Hal ini disebabkan karena cara Ibn Qudamah memakai dan menerapkan dalil-dalil yang lebih menekankan pada konteks hadis, tanpa banyak terjebak pada tekstualitas yang kaku. Selain itu pengaruh metode istidlal Imam Ahmad Ibn Hanbal, tampaknya turut berpengaruh pada metode argumentasi Ibn Qudamah yang menempatkan fatwa sahabat Nabi sebagai sumber rujukan ketiga setelah al-Qur'an dan as-Sunnah yang shahih (Ashsiddieqy, 1953: 55) sementara hadis-hadis mursal dan hadis dha'if ditempatkan pada posisi setelah fatwa sahabat Nabi. Hal ini berarti bagi Ibn Qudamah bahwa pendapat sahabat Nabi yang sebetulnya memuat rasionalitas argumentasi sahabat atas suatu masalah lebih kuat ketimbang teks-teks hadis mursal dan hadis dha'if. Dengan demikian, metode istidlal yang dipergunakan oleh Ibn Qudamah dalam memahami dalil serta melakukan argumentasi hukum didasarkan pada pertimbangan rasional. Artinya, selain meletakkan al-Qur'an dan as-Sunnah serta fatwa sahabat sebagai sumber rujukan pertama, Ibn Qudamah juga 
mempergunakan ra'yu (rasional) dan analisis kontekstual, yaitu (analisis yang didasarkan atas kondisi sosio-kultural masyarakatnya) dalam menetapkan sebuah hukum. Jika dikaitkan dengan istinbat hukum yakni metodologi untuk memahami, menetapkan dan menerapkan hukum Islam, maka sesungguhnya posisi istidlal berada dalam bagian-bagian dari proses istinbat tersebut. Lebih jelasnya, metode istidlal menjadi bagian untuk memahami dalildalil syara' yang akan dipergunakan untuk melakukan proses istinbat.

\section{Wakaf dalam Pandangan Mazhab Hanafi dan Ibn Qudama}

Kata wakaf atau wakf berasl dari bahasa arab "waqafa" asal kata "waqafa" berarti "menahan" atau "berhenti" atau diam di tempat atau tetap berdiri. Kata "waqafa-yaqifu-waqfan" sama artinya dengan "Hasaba-Yasibu-Tahbisan" (Salim, 1993: 893) kata al-waqf dalam bahasa Arab mengandung beberpa pengertian, yaitu menahan harta untuk diwakafkan, tidak dipindahkan (Departemen Agama, 2003: 1). Menurut istilah fiqh, para ahli fiqh berpendapat dalam mendefiniskan wakaf menurut istilah, sehingga mereka berbeda pula dalam memandang hakekat wakaf itu sendiri, berbagai pandangan tentang wakaf itu sendiri menurut istilah sebgai berikut: pertama, Abu Hanifah, wakaf adalah menahan benda yang menurut hukum, tetap menjadi milik si wakif dalam rangka mempergunakan manfaatnya untuk kebajikan. Berdasarkan definisi ini maka kepemilikan harta wakaf tidak lepas dari si wakif, bahkan ia dibenarkan menarik kembali dan ia boleh menjualnya, jika si wakif wafat, harta tersebut menjadi harta warisan buat ahli waris, maka yang timbul dari wakaf adalah "menyumbangkan manfaat" karena itu mazhab Hanafi mendefiniskan wkaf adalah "tidak melakukan suatu tindakan atas suatu benda, yang berstatus tetap sebgai hak milik, dengan menyedekahkan manfaatnya kepada suatu pihak kebajikan (sosial), baik sekarang maupun akan datang" seperti wakaf buah kelapa. Kedua, Mazhab Maliki, berpendapat "bahwa wakaf itu tidak melepaskan harta yag diwakafkan dari kepemilikan wakif, namun wakif tersebut mencegah wakaf melakukan tindakan yag dapat melepaskan kepemilikannya atas harta tersebut kepada yang lain dan wakif berkewajiban menyedekahkan anfaat serta tidak boleh menarik kembali wakafnya. Ketiga, Mazhab Syafi'i dan Ahmad Hambal, Syafi'i dan Ahmad berpendapat bahwa wakaf adalah melepaskan harta yang diwakafkan dari kepemilikan si wakif, setelah sempurna prosedur perwakafan. Wakif tidak boleh melakukan apa saja terhadap harta uang yang diwakafkan, seperti: perlakuan pemilik dengan cara memindahkan kepemilikan kepada yang lain, baik dengan tukaran (tukar-menukar) atau tidak. Jika wakif wafat, harta yang diwakafkan tidak dapat diwarisi oleh ahli warisnya, wakif menyalurkan manfaat harta yang diwakafkannya kepada mauquf alaih (yag diberi wakaf) sebagai sedekah yang mengikat, dimana wakif tidak dapat melarang penyaluran sumbangan tersebut, apabila wakifnya melarangnya, maka qadli berhak memaksanya agar memberikan kepada mauquf alaih, karean itu mazhab Syafi'i mendefinisakna wakaf adalah: tidak melakukan suatu tindakan atas suatu benda, yang berstatus sebgai milik Allah Swt, dengan menyedekahkan manfaat 
kepada suatu kebajikan (sosial). Keempat, Mazhab Imamiyah lain sama dengan mazhab ketiga, namun berbeda dari segi kepemilikan atas benda yang diwkafkan yaitu milik mauquf alaih, (yang diberi wakaf) meskipun mauquf alaih tidak berhak melakukan suatu tindakan atas benda wakaf tersebut, baik menjual atau menghibahkan (Departemen Agama RI, 2007: 2-4).

Pengertian wakaf uang, sejak awal perbincangan tentang wakaf kerap diarahkan kepada benda wakaf yang tidak bergerak, sedangkan wakaf benda bergerak baru mengemuka belakangan. Di antara wakaf benda bergerak yang ramai diperbincangan belakannga adalah wakaf yang dikenal dengan cash wakaf. Cash wakaf diterjemahkan dengan wakaf tunai. Namun kalau pemilik objek barangnya, yaitu uang, lebih tepat kiranya kalau cash wakaf diterjemahkan dengan wakaf uang. Wakaf uang adalah wakaf yang dilakukan oleh seseorang, kelompok orang dan lembaga atau badan huku dalam bentuk tunai/uang. Hukum wakaf unag telah menjadi perhatian para fuqaha (juris Islam), beberpa sumber menyebutkan bahwa wakaf uang telah dipraktekkan oleh masyarakat yang menganut mazhab Hanafi, ialah dengan mewakafkan uang yaitu dengan melakuan atau menjadikan modal usaha dengan cara mudharabah atau mubadha'ah. Sedangkan keuntungan diserahkan kepada pihak wakaf. Ibnu Abidin mengemukakan bahwa wakaf uang tidak boleh atau tidak sah. Yang juga berpandangan bahwa wakaf uang tidak boleh adalah mazhab Syafi'i, menurut alBakri mazhab Syafi'i tidak memperbolehkan wakaf uang, karena dinar dan dirham akan lenyap ketika dibayarkan sehingga tidak ada lagi wujudnya. Perbedaan pendapat di atas, bahwa alasan boleh tidaknya wakaf uang berkisar pada wujud uang, apakah wujud uang digunakan atau dibayarkan, masih ada seperti semula, terpelihara dan mendapatkan atau menghasilkan keuntungan pada waktu yang lama? Namun kalau melihat perkembangan sistem perekonomian yang berkembang sekarang, sangat memungkinkan untuk melaksanakan wakaf uang, misalnya wakaf uang atau uang yang diwakafkan dijadikan modal usaha seperti yang dikatakan oleh mazhab Hanafi atau diinvestasikan dalam wujud saham dan deposito, atau yang lebih tepatnya nilai uang tetap maka akan terpelihara keuntungan akan pada wakatu yang lama (Departemen Agama RI, 2007: 3-6).

Berbeda dengan mazhab lainnya, menurut pendapat Ibn Qudamah bahwa, wakaf terwujud kecuali bila orang yang mewakafkan bermaksud mewakafkan barangnya untuk selamalamanya dan terus menerus. Jadi, kalau orang yang mewakafkan itu membatasi waktunya untuk jangka waktu tertentu, misalnya mengatakan, "saya mewakafkan barang ini untuk waktu sepuluh tahun." Atau "bila saya membutuhkannya", atau dengan syarat bisa saya tarik kembali kapan saja saya mau", "bila saya membutuhkannya", atau "bila anak saya membutuhkannya" dan redaksi-redaksi seperti itu, maka apa yang dilakukannya itu tidak bisa disebut sabagai wakaf dalam pengertian yang benar (Mughniyah, 2001: 636). Ibn Qudamah lebih jauh berpendapat bahwa wakaf harus memenuhi beberapa syarat, yaitu pertama, benda wakaf harus jelas, dapat diketahui secara nyata dan manfaatnya bertahan lama. Misalnya, benda-benda tidak bergerak (tanah, kebun), berupa hewan, 
perabotan rumah tangga, senjata, harta bersama saham dan lain-lain sebagainya. Tapi tidak boleh mewakafkan hutang dan rumah yang menjadi tempat tinggal (Al-Buhuty, 982: 243-251). Kedua, dari perspektif hukum, kepemilikan atas harta wakaf terletak di luar orang yang membuat wakaf. Beberapa ahli hukum Islam berpendapat bahwa hak pemilik harta wakaf ada pada Allah. Ulama lain berpendapat dalam pengertian bahwa wakaf mereka tidak diizinkan untuk untuk mengalihkan (menjual) harta wakaf atau menggunakannya di luar ketentuan yang disyartakan oleh orang yang berwakaf (waqif). Dalam konteks ini, menjual hartanya, ini berarti bahwa wakaf itu lebih kekal dibandingkan dengan yayasan. Ketiga, kekal di sini berarti bahwa begitu semua harta diwakafkan, biasanya berupa (sebidang) tanah, selamanya tanah tersebut menjadi harta wakaf. Penghapusan harta wakaf membutuhkan prosedur yang panjang dan rumit, harta wakaf hanya dapat diganti dengan harta lain yang sama nilainya. Pengalihan harta wakaf memerlukan persetujuan dengan pengadilan setempat. Begitu adanya penggantian, harta pengganti tersebut langsung menjadi harta yang fungsi dan tujuannya sama dengan harta wakaf yang digantikan. Dengan demikian, yang dimaksud dengan kekal adalah bahwa harta wakaf tidak boleh berkurang, karena sifat wakaf itulah, banyak ahli hukum Islam menetapkan bahwa wakaf seharusnya diterapkan pada tanah semata. Ada ahli hukum yang menerima gagasan ketahanlamaan sebagai pendekatan terhadap pengertian kekekalan, oleh karena itu, buku, senjata, hewan pembajak, tanah, mesin, dan uang dapat dijadikan wakaf (Esposito, 2001: 146).

Perbuatan wakaf dinilai ibadah yang senantiasa mengalir pahalanya apabila harta wakaf itu dapat memenuhi fungsinya yang dituju. Dalam hal harta wakaf berkurang, rusak atau tidak dapat memenuhi fungsinya sesuai dengan tujuannya, harus dicarikan jalan keluar agar harta itu tidak berkurang, utuh, dan berfungsi. Bahkan untuk menjual atau menukar pun tidak dilarang, kemudian ditukar dengan benda lain yang dapat memenuhi tujuan wakaf (Suhendi, 2002: 19). Sebelum melangkah lebih jauh penulis terlebih dahulu menjelaskan makna perubahan itu sendiri, perubahan yang dimaksud di sini adalah ibdal bahwa menjual atau merubah harta wakaf adalah untuk mengganti harta wakaf yang telah rusak dengan benda lain. Sedangkan istibdal adalah menjadikan barang lain sebagai pengganti harta wakaf yang asli atau yang telah dijual (al-Kabisi, 2004: 349).

Pada hakekatnya semua ulama sepakat tentang adanya larangan merubah harta wakaf. Seperti tertuang dalam hadis riwayat 'Umar, hanya saja ada sebagian ulama seperti halnya Ibn Qudamah yang membolehkan merubah status harta wakaf (Qudamah, tt: 632). Kalau memang kamanfaatan dari harta wakaf itu telah berkurang atau habis sehingga diperbolehkan merubah harta wakaf tersebut dengan harapan kelangsungan dari tujuan wakaf itu bisa berlanjut dan berkesinambungan. Hal ini sejalan dengan pendapat Imam Ahmad ibn Hanbal dan Abu Saur yang dikutip oleh Suparman, tentang bolehnya merubah harta wakaf yang sudah tidak berfungsi atau berkurang fungsinya. Kebolehan itu dengan alasan supaya benda wakaf tersebut bisa 
berfungsi (maslahah) sesuai dengan tujuan wakaf atau untuk mendapatkan maslahah yang lebih baik bagi kepentingan manusia umumnya (Usman, 1997: 39).

Perubahan harta wakaf dapat dilakukan dengan alasan: pertama, penggantian karena kepentingan yang lebih baik. Misalnya menggantikan hadiah dengan sesuatu yang lebih baik daripadanya. Misalnya masjid yang dibangun sebagai ganti dari masjid yang lama, agar lebih layak bagi masyarakat (al-Buhuty, tt: 149). Kedua, perubahan harta wakaf karena adanya kebutuhan. Misalnya benda itu rusak, maka ia dijual dan harganya dipergunakan untuk membeli sesuatu yang dapat menggantikannya. Seperti kuda yang diwakafkan untuk perang, bila tidak mungkin dimanfaatkan di dalam perang, maka ia dijual dan hasil penjualannya dipergunakan untuk membeli barang yang dapat menggantinya. Misalnya masjid, bila tempat disekitarnya rusak, maka ia dipindahkan ke tempat lain atau dijual dan harga penjualannya dipergunakan untuk membeli apa yang dapat menggantikannya. Semua ini diperbolehkan, karena bila yang pokok (asal) tidak dapat untuk mencapai tujuan, maka digantikan oleh yang lainnya (Qudamah, tt: 632).

Pendapat Ibn Qudamah juga ijtihad yang dilakukan 'Umar ibn Khattab yang pernah memindahkan masjid Kufah yang lama ke tempat yang baru, tempat yang lama dijadikan pasar penjual-jual tamar (Qudamah, tt: 632). Bahwa menjual, menukar harta wakaf tidaklah ada halangan, asal penjualannya atau penukarannya itu digunakan lagi sebagai harta wakaf. Jadi, pokok masalahnya adalah kemaslahatan dan manfaatnya. Dalam hal ini, ilmu fiqh mengenal prinsip maslahah (memelihara maksud syara' yaitu memberikan kemanfaatan dan menghindari hal-hal yang merugikan), sehingga tidak tepat kiranya bila harta wakaf yang rusak atau tidak memenuhi fungsinya lagi sebagai harta wakaf untuk tujuan tertentu kemudian dibiarkan tanpa tindakan positif (Anshori, 2006: 37). Sesungguhnya yang menjadi pokok di sini adalah menjaga kemaslahatan. Allah mengutus pesuruhNya guna menyempurnakan kemaslahatan dan melenyapkan segala kerusakan (Rasjid, 1992: 132).

Pada kasus seperti apa yang telah dilakukan oleh Umar dan Usman Ibn Affan pernah membangun masjid Nabawi tanpa mengikuti konstruksi bangunan lama dan dengan memberi beberapa tambahan. Adapun benda yang diwakafkan untuk diproduksikan, apabila diganti dengan yang lebih baik, seperti wakaf rumah, kedai, kebun, yang diproduksikan kecil, kemudian diganti yang lebih baik, maka hal itupun diperbolehkan. Dengan pendapat Abu Saur dan ulama-ulama lainnya, seperti Abu Ubaid Ibn Harawabaih, hukum Mesir yang memtuskan seperti itu. Peristiwa wakaf itu merupakan qiyas dari ucapan Ibn Hanbal tentang pemindahan masjid dari satu tempat ke tempat lain karena adanya maslahat. Bahkan diperbolehkan menggantikan satu masjid dengan yang bukan masjid karena adanya kemaslahatan. Hal yang demikian disebabkan karena menggantikan suatu obyek dengan obyek lainnya yang lebih utama dan layak (As Sabiq, 1983: 387).

Adapun ketentuan hukum (dalil) yang digunakan oleh Ibn Qudamah 
dalam menetapkan hukum tentang kebolehan merubah harta wakaf secara garis besar ada dua, yakni hadis riwayat Ibn Zubair, fatwa sahabat juga beberapa riwayat tentang kebolehan merubah harta wakaf. Di antara dalildalil tersebut yaitu: pertama, fatwa sahabat. Fatwa sahabat di sini adalah perbuatan sahabat Umar ibn Khattab yang pernah memindahkan Masjid Kufah yang lama ke tempat yang baru, dan tempat yang lama dijadikan pasar bagi para pedagang dan inipun diketahui oleh para sahabat dan tidak ada yang mengingkari (Qudamah, tt: 632). Dan juga perbuatan sahabat Umar dan Usman yang pernah membangun Masjid an-Nabawi dengan tidak mengikuti konstruksi bangunan awal dengan memberi tambahan (As Sabiq, 1983: 531). Dalam teori ushul fiqh Ahmad ibn Hanbal, perbuatan sahabat Umar ini juga masuk dalam kategori ijma', yakni perbuatan seorang sahabat yang di situ tidak ada sahabat lain yang menolak keputusan tersebut, karena yang demikian itu merupakan ijma (Shidieqy 1997: 59). Karena pada dasarnya, Imam Ahmad ibn Hanbal tidak mengakui ijma' setelah sahabat (at-Tarikhi, tt: 333) karena ijma' sahabat menduduki derajat utama dari bermacam-macam ijma' (at-Tarikhi, tt: 334). Kedua, pada hakekatnya semua ulama sepakat tentang adanya larangan merubah harta wakaf, seperti tertuang dalam hadis riwayat Umar ibn Khattab hanya saja ada sebagian ulama seperti halnya Ibn Qudamah yang membolehkan merubah harta wakaf (Qudamah, tt: 632), dalam hal ini masjid. Kalau memang kemanfaatan dari harta benda wakaf itu telah berkurang atau habis sehingga diperbolehkan merubah harta wakaf tersebut dengan harapan kelangsungan dari tujuan wakaf bisa berlanjut dan berkesinambungan. Hal ini sejalan dengan pendapat Ibn Qudamah, Abu Saur, yang dikutip oleh Suparman Usman tentang bolehnya merubah harta wakaf yang sudah tidak berfungsi atau berkurang fungsinya. Kebolehan merubah harta wakaf dengan alasan supaya benda wakaf tersebut bisa berfungsi (mashlahah) sesuai dengan tujuan wakaf atau untuk mendapatkan mashlahat yang lebih baik bagi kepentingan manusia umunya (Usman, 1997: 39). Pendapat pertama dan kedua tadi membutuhkan landasan dalil dari al-Quran dan hadis, maka argument yang ketiga, hadis yang digunakan oleh Ibn Qudamah dalam berargumentasi tentang kebolehan merubah harta wakaf yakni hadis riwayat Ibn Zubair dalam kitab Bukhari yang berbunyi:

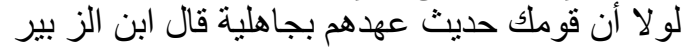
لنقضت الكعبة فجعلت لها بابين يدخل الناس وباب الز ابن

يخرجون منها.

Kalau dilihat dari teks hadis di atas pada dasarnya perubahan atau pemugaran Ka'bah itu belum terjadi. Hal ini dapat diketahui dari hadis di atas bahwa seandainya ada alasan yang kuat tentulah Nabi mengubah bangunan Ka'bah. Lebih lanjut Ibn Qudamah mengatakan boleh merubah harta wakaf karena adanya mashlahah yang rajih dan adanya hajat bagi objek wakaf untuk menyempurnakan manfaat benda wakaf, bukan karena adanya darurat sehingga membolehkan hal-hal yang terlarang. Dengan demikian boleh merubah harta wakaf karena untuk menyempurnakan manfaatnya tidak dengan kondisi mendesak. Di samping berdasarkan hadis dan juga ijma' seperti tersebut di atas Ibn Qudamah juga menggunakan beberapa riwayat untuk 
menguatkan pendapatnya antara lain riwayat Abu Daud (Qudamah, tt: 632) yang mengatakan:

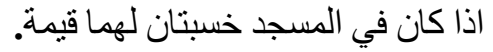

Lebih lanjut Ibn Qudamah mengemukakan argumentasinya seperti dikutip Ahmad Rafiq, bahwa tindakan merubah harta wakaf tersebut ditempuh adalah untuk menghindari kemungkinan timbulnya kerusakan dan setidaknya menyia-nyiakan harta wakaf (Al 'Asimi, tt: 213). Seperti kaidah ushul fiqh mengatakan:

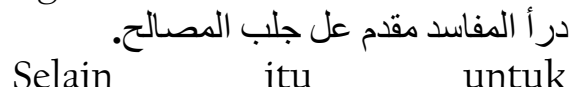
mempertahankan tujuan hakiki disyari'atkannya wakaf yaitu untuk kepentingan orang banyak dan berkesinambungan (Rafiq, 2001: 132). Ibn Qudamah juga memfatwakan bolehnya merubah bagian wakaf yang rusak demi memperbaiki bagian yang lain. Itu semua adalah demi kemaslahatan.

Ibn Hajar menulis dalam kitabnya "sah menjual atau merubah sebagian harta wakaf demi memperbaiki sebagian yang lain. Dengan syarat waqif dan penerima wakafnya harus sama". Pendapat ini ditentang oleh al-Mawardi, beliau menyatakan Ahmad ibn Hanbal berkata: "sah menjual atau merubah sebagian harta wakaf untuk memperbaiki sebagian yang lain. Ini adalah pendapat yang salah karena Rasulullah Saw telah bersabda: "Bentuk asli harta wakaf harus tetap dipertahankan dan manfaatnya harus disedekahkan. Dengan dasar hadis ini, kita tidak boleh menghilangkan harta wakaf. Jika kita dilarang menjual atau merubah keseluruhan harta wakaf. Tentunya kita juga dilarang menjual sebagiannya (al-Kabisi, 2004: 378). Dari keterangan di atas dapat dilihat bahwa, pendapat Ibn Qudamah dalam menetapkan hukum tentang perubahan status harta wakaf memberikan kelonggaran, karena menurutnya apabila ada alasan yang jelas atau kondisi menuntut untuk diadakan perubahan pada wakaf (tidak merugikan bagi kepentingan umum) dan berdasarkan maslahat maka hal itu diperbolehkan. Lebih lanjut kelonggaran yang diberikan oleh Ibn Qudamah dari pemaparan di atas dapat dilihat bahwa Ibn Qudamah sangat mempertimbangkan situasi dan kondisi dari keberadaan harta wakaf demi mencapai tujuan diwakafkannya harta tersebut. Ibn Qudamah berpendapat bahwa, jika kita melarang perubahan atau penggantian harta wakaf sementara ada alasan lain untuk itu, maka kita termasuk menyia-nyiakan wakaf. Akibatnya, harta wakaf bisa menjadi rusak dan tidak bisa dimanfaatkan lagi. Misalnya, rumah akan menjadi rusak dan tidak terurus, atau tanah akan hancur dan tidak dapat ditanami lagi. Larangan ini hanya akan merugikan keseluruhan umat. Khususnya kaum fakir miskin yang telah ditentukan sebagai penerima wakaf. Dengan tetap memegang prinsip bahwa wakaf itu abadi dan harus dijaga serta dipelihara sesuai dengan jenis barang dan cara pemeliharaan yang disyaratkan waqif dengan tidak melarang penggantian atau penjualannya ketika ada hal yang menghalangi pemeliharaan asal jenis barang atau bentuknya. Karena, bila barang wakaf rusak dan tidak bisa dimanfaatkan lagi yang mengakibatkan tidak tercapainya tujuan wakaf, maka hal itu bisa direduksi dengan mengganti atau menjualnya, sehingga kita dapat 
mengabadikan maksud dan tujuan wakaf tersebut. Meski hukum ini hanya didasarkan pada pertimbangan logika, namun menurut penulis, jika hukum ini dilaksanakan sesuai dengan kaidahkaidah syariat, tentu akan memberi manfaat kepada umat khusunya penerima wakaf.

Hanya saja, pada praktiknya sering kali kita menemukan aspekaspek yang dikhawatirkan bisa menghilangkan barang wakaf atau mengakibatkan tidak tersalurkannya keuntungan kepada yang berhak. Oleh karena itu, penggantian harta wakaf harus dilakukan dengan ekstra hati-hati dan melalui pertimbangan yang matang. Dalam sejarah kaum muslimin pun, kita sering menemukan literatur-literatur yang menyebutkan bahwa sebagian penguasa muslim terkadang menyalahgunakan izin penggantian pribadi. Mereka mengkorupsi dan mengahambur-hamburkan harta wakaf. Menyedihkan memang, tapi yang lebih ironis lagi, mereka melakukan hal itu dengan sepengetahuan dan persetujuan hakim-hakim zalim atau saksi-saksi yang bersumpah palsu.

Seperti di Irak memperbolehkan penggantian harta wakaf jika waqif mensyaratkan hal itu ketika akad. Ada alasan yang mendesak dan demi pertimbangan kemaslahatan bersama. Lembaga wakaf di Irak yang mengambil sikap demikian, karena mereka menyaksikan banyak harta wakaf di negara itu yang mengalami kerusakan dan tidak bermanfaat sedikit pun, atau masih bermanfaat namun keuntungan yang didapat kecil dan tidak dapat penutup biaya pengelolaan. Seandainya harta wakaf itu diganti dengan barang lain, akan memberikan keuntungan yang lebih besar.
Meski demikian, penggantian harta wakaf di sana tidak bisa begitu saja dilakukan. Penggantian harus dilakukan melalui keputusan Mahkamah Syari'ah. Dalam alinea pertama pasal 6 Undang-undang Wakaf No. 107 Tahun 1964, disebutkan: kementerian berhak mengganti harta wakaf, baik dengan barang lain maupun dengan uang dengan pertimbangan maslahat. Hal itu dilaksanakan atas persetujaun majelis hakim dan Mahkamah Syari'ah yang disahkan dengan surat keputusan dari pemerintah (Al-Kabisi, 2004: 382).

\section{Relevansi dengan Perkembangan Wakaf di Indonesia}

Di beberapa negara di dunia ini, telah melakukan pembenahan dalam perundang-undangan yang ada kaitannya dengan kesejahteraan masyarakat, tidak terkecuali di beberapa negara yang mayoritas penduduknya beragama Islam, salah satunya Indonesia. Dalam hal ini, pemerintah Indonesia telah menetapkan Undang-Undang No. 41 tahun 2004 yang berkaitan dengan wakaf.

Pengertian wakaf menurut Undang-Undang Wakaf No. 41 tahun 2004 wakaf adalah perbuatan hukum waqif untuk memisahkan dan atau menyerahkan sebagian harta benda miliknya untuk dimanfaatkan selamanya atau untuk jangka waktu tertentu sesuai dengan kepentingannya guna keperluan ibadah dan atau kesejahteraan umum menurut syari'ah (Redaksi Fokus Media, 2005: 94), dalam hal ini bisa disebut dengan konsep maslahat.

Berdasarkan konsep Ibnu Qudamah tentang bolehnya merubah 
harta wakaf lebih ditekankan pada manfaat harta wakaf. Penekanan pada manfaat harta wakaf ini, dimaksudkan untuk mendapatkan kemaslahatan sesuai dengan tujuan wakaf atau untuk mendapatkan maslahat yang lebih baik bagi kepentingan manusia umumnya. Kondisi ini akan lebih bermanfaat ketimbang membiarkan harta wakaf tersebut tidak atau kurang memenuhi fungsinya sebagai harta wakaf. Hal ini dapat dibuktikan dengan melihat metode istidlal Ibn Qudamah dalam menetapkan sebuah hukum. Seperti cara dia menetapkan hukum perubahan status harta wakaf, Ibn Qudamah menggunakan dalil hadits yang diriwayatkan Bukhari sebagai berikut:

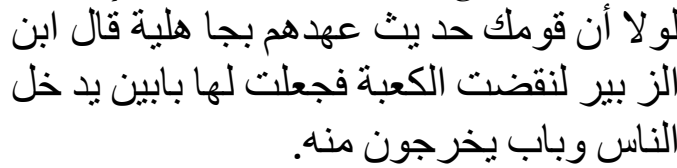

Penggunaan dalil ini sebagai basis istidlal Ibnu Qudamah dalam menetapkan perubahan status harta wakaf memberikan gambaran bahwa meski perubahan dan pemugaran Ka'bah sebagai harta wakaf belum dilakukan, tetapi jika hal itu memberikan dampak positif pada pemanfaatannya, maka pemugaran tersebut dapat dilakukan. Dari sini, dapat dipahami bahwa metode argumentasi Ibn Qudamah didasarkan pada logika berpikir yang rasional. Hal ini disebabkan karena cara Ibn Qudamah memakai dan menerapkan dalil-dalil yang lebih menekankan pada konteks hadis, tanpa banyak terjebak pada teks-teks hadis secara ketat. Dengan prinsip kemaslahatan tersebut, praktik perwakafan untuk kondisi saat ini dapat diwujudkan dan mengoptimalkan fungsi dan tujuan wakaf itu sendiri. Untuk konteks
Indonesia, tampaknya praktik perwakafan yang dilaksanakan oleh 'Umar Ibn Khattab, dan apa yang difatwakan oleh Ibn Qudamah sejalan dengan praktik perwakafan di Indonesia. Hal ini dapat dilihat pada tata cara perubahan harta wakaf di Indonesia.

Dalam Undang-Undang Republik Indonesia Nomor 41 Pasal 40 Tahun 2004, disebutkan bahwa:

Harta benda wakaf yang sudah diwakafkan dilarang: (a) dijadikan jaminan, (b) disita, (c) dihibahkan, (d) dijual, (e) diwariskan, (f) ditukar atau (g) dialihkan dalam bentuk pengalihan hak lainnya.

Tetapi jika pada realitasnya, harta benda wakaf ini berkurang fungsinya atau mengalami alih fungsi, maka perubahan tersebut masih bisa ditolerir. Seperti yang diatur dalam Undang-Undang Wakaf Tahun 2004 Pasal 4l, dikatakan bahwa jika harta yang telah terlanjur diwakafkan akan digunakan untuk kepentingan umum dan sesuai dengan rencana umum tata ruang (RUTR) dan berdasarkan ketentuan peraturan perundangundangan serta tidak bertentangan dengan syari'ah (ayat 1), maka tindakan untuk merubah status harta wakaf tersebut dapat diterima. Hanya saja, menurut Undang-Undang Wakaf Republik Indonesia Tahun 2004 ini, ketika status harta wakaf tersebut berubah, maka wajib ditukar dengan harta benda yang memiliki manfaat dan nilai tukar yang relatif sama dengan harta wakaf sebelumnya (ayat 3).

$$
\text { Pada tahap selanjutnya, }
$$

perubahan atas status harta wakaf 
dapat dilakukan jika memiliki alasanalasan tertentu dan mendapat persetujuan dari Menteri Agama. Persetujuan itu hanya dapat terjadi dengan alasan Karena tidak sesuai lagi dengan tujuan wakaf sebagaimana yang dikehendaki dalam ikrar wakaf dan Karena kepentingan umum. Dari paparan materi Undang-undang Wakaf Tahun 2004 tentang perubahan status harta wakaf di Indonesia, dapat dilihat bahwa meski sejatinya harta wakaf tidak boleh dihibahkan, dijual, diwariskan, ditukar dan dialihkan, tetapi jika dalam keadaan tertentu harta tersebut harus dialihfungsikan untuk kepentingan umum, atau untuk aturan tata ruang, maka undang-undang pun mentolerir adanya perubahan status tersebut. Ini berarti bawha undangundang wakaf di Indonesia sangat fleksibel, akomodatif dan sejalan dengan program pembangunan fisik yang sedang digalakkan pemerintah Indonesia sejak era Orde Baru.

Dari keterangan di atas dapat dilihat bahwa, materi Undang- Undang Wakaf di Indonesia Tahun 2004 secara prinsipil sangat relevan dengan perubahan status harta wakaf yang dikonsepsikan oleh Ibnu Qudamah. Bagi Ibn Qudamah, dalam menetapkan hukum tentang perubahan status harta wakaf harus memberikan kelonggaran, karena menurutnya apabila ada alasan yang jelas atau kondisi menuntut untuk diadakan perubahan pada wakaf (tidak merugikan bagi kepentingan umum) dan berdasarkan maslahah maka hal itu diperbolehkan. Jadi, pokok masalahnya adalah kemaslahatan dan manfaatnya. Dalam hal ini, ilmu fiqh mengenal prinsip maslahah (memelihara maksud syara' yaitu memberikan kemanfaatan dan menghindari hal-hal yang merugikan), sehingga tidak tepat kiranya bila harta wakaf yang rusak atau tidak memenuhi fungsinya lagi sebagai harta wakaf untuk tujuan tertentu kemudian dibiarkan tanpa tindakan positif (Anshori, 2006: 37). Sesungguhnya yang menjadi pokok di sini adalah menjaga kemaslahatan.

Lebih lanjut kelonggaran yang diberikan oleh Ibn Qudamah dari pemaparan di atas, dapat dilihat bahwa Ibn Qudamah sangat mempertimbangkan situasi dan kondisi dari keberadaan harta wakaf demi mencapai tujuan diwakafkannya harta tersebut. Ibn Qudamah berpendapat bahwa, jika kita melarang perubahan atau penggantian harta wakaf sementara ada alasan lain untuk itu maka kita termasuk menyia-nyiakan wakaf. Akibatnya, harta wakaf bisa menjadi rusak dan tidak bisa dimanfaatkan lagi. Misalnya, rumah akan menjadi rusak dan tidak terurus, atau tanah menjadi tidak berguna dan tidak dapat ditanami lagi. Larangan ini hanya akan merugikan keseluruhan umat. Khususnya kaum fakir miskin yang telah ditentukan sebagai penerima wakaf. Dengan tetap memegang prinsip bahwa wakaf itu abadi dan harus dijaga serta dipelihara sesuai dengan jenis barang dan cara pemeliharaan yang disyaratkan waqif dengan tidak melarang penggantian atau penjualannya ketika ada hal yang menghalangi pemeliharaan asal jenis barang atau bentuknya. Karena, bila barang wakaf rusak dan tidak bisa dimanfaatkan lagi yang mengakibatkan tidak tercapainya tujuan wakaf, maka hal itu bisa direduksi dengan mengganti atau menjualnya, sehingga kita dapat mengabadikan maksud dan tujuan wakaf tersebut. Meski hukum ini hanya 
didasarkan pada pertimbangan logika, namun menurut penulis, jika hukum ini dilaksanakan sesuai dengan kaidahkaidah syari'at, tentu akan memberi manfaat kepada umat khusunya penerima wakaf.

Berangkat dari perspektif Ibn Qudamah ini, tampaknya sangat sejalan dengan kebijakan pemerintah dan keputusan hukum dari Badan-badan hukum yang terlibat dalam pembuatan Undang-undang Wakaf dalam hal penggusuran masjid yang berstatus sebagai harta wakaf menjadi pelebaran jalan untuk kepentingan umum. Dalam hal ini, pendapat Ibn Qudamah sangat relevan dengan Undang-undang Wakaf No. 41 pasal 41 tahun 2004, dapat dilihat dengan adanya persamaan antara pendapat Ibn Qudamah dengan Undang-undang ini. Berdasarkan kasus ini, disebabkan oleh pijakan hukum yang keduanya lebih menekankan aspek manfaat yang ditimbulkan dari harta wakaf, relevan ketika sebuah harta wakaf tidak lagi berfungsi, kurang fungsinya, atau posisi hukum pindahnya lebih dibutuhkan terhadap harta wakaf itu, maka cara penyelesaian masalah tersebut adalah dengan menukarkan harta wakaf dengan harta wakaf lain yang lebih berfungsi, tetapi status hukumnya tetap sebagai harta wakaf seperti semula.

Selain itu, berangkat dari konteks Indonesia yang berada dalam era pembangunan dengan idealis developmentalism yang diusung pemerintah Orde Baru saat itu, maka pembangunan fisik seperti jalan, jembatan, masjid dan lain-lain lebih digalakkan. Ketika pembangunan fisik terjadi benturan dengan masalahmasalah yang berkaitan dengan agama, seperti penggusuran harta wakaf, maka pemerintah pun mencari jalan keluar dengan menjalankan kebijakan hukum Islam yang berkiblat pada mazhab yang mampu mendukung program itu. Oleh karena itu, meski Ibn Qudamah merupakan ulama yang bermazhab Hambali, pendapatnya kembali diadopsi sebagai basis kebijakan hukum Islam sebab pendapatnyalah yang paling bisa mendukung untuk melanjutkan program tersebut. Dengan kata lain, selain pendapatnya tentang penekanan nilai manfaat harta wakaf, tingkat relevansi pendapat Ibn Qudamah dengan Undang-undang Wakaf No. 41 pasal 41 tahun 2004 di Indonesia, juga pada segi kemampuan adaptif dan aplikasinya pada problemproblem sosial kemasyarakatan yang ada di Indonesia.

\section{E. Kesimpulan}

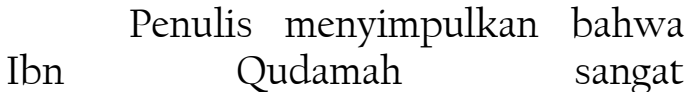
mempertimbangkan situasi dan kondisi dari keberadaan harta wakaf demi mencapai tujuan diwakafkannya harta tersebut. Ibn Qudamah berpendapat bahwa, jika kita melarang perubahan atau penggantian harta wakaf sementara ada alasan lain untuk itu maka kita termasuk menyia-nyiakan wakaf. Harta wakaf bisa menjadi rusak dan tidak bisa dimanfaatkan lagi. Misalnya, rumah akan menjadi rusak dan tidak terurus, atau tanah menjadi tidak berguna dan tidak dapat ditanami lagi. Larangan ini hanya akan merugikan keseluruhan umat. Khususnya kaum fakir miskin yang telah ditentukan sebagai penerima wakaf. Dengan tetap memegang prinsip bahwa wakaf itu abadi dan harus dijaga serta dipelihara sesuai dengan jenis barang dan cara pemeliharaan yang 
disyaratkan waqif dengan tidak Al-Jauziyyah, Ibnu Qayyim. Tt. I'lam almelarang penggantian atau penjualannya ketika ada hal yang menghalangi pemeliharaan asal jenis barang atau bentuknya. Bila barang wakaf rusak dan tidak bisa dimanfaatkan lagi yang mengakibatkan tidak tercapainya tujuan wakaf, maka hal itu bisa direduksi dengan mengganti atau menjualnya, sehingga kita dapat mengabadikan maksud dan tujuan wakaf tersebut. Meski hukum ini hanya didasarkan pada pertimbangan logika, namun menurut penulis, jika hukum ini dilaksanakan sesuai dengan kaidahkaidah syariat, tentu akan memberi manfaat kepada umat khusunya penerima wakaf.

Pendapat Ibn Qudamah sangat relevan dengan Undang-Undang Wakaf No. 41 pasal 41 tahun 2004, dapat dilihat dengan adanya persamaan antara pendapat Ibn Qudamah dengan Undang-undang ini.

\section{DAFTAR PUSTAKA}

Al-Bukari. 1981. Shahih al-Bukhari III. Beirut: Dar al-Fikr.

Adijani, Al-Alabij. 2002. Perwakafan Tanah di Indonesia dalam Teori dan Praktek. Jakarta: Raja Grafindo Persada.

Anshori, Abdul Ghofur. 2004. Hukum dan Praktik Perwakafan. Yogyakarta: Pilar Indonesia.

Asimi, Rahman Ibn Qasim al Abu Abdur ar. Tt. Majmu' Fatawa, Beirut: Dar asSadr.

Al-Buhuty, Mansur ibn Yunus ibn Idris. 1982. Kasysyaf al-Qina. Beirut: Dar al-Fikr.

Al-Husaini, H.M. al-Hamid. 1999. Riyawat Sembilan Imam Fiqh. Jakarta: Pustaka Hidayah. Muwaqqi'In 'an-rabb al-Alamin, Beirut: Darl al-Jail.

Al-Kabisi, Muhammad Abid Abdullah. 2004. Hukum Wakaf. Ciputat: Iiman.

Al-Muhsin, at-Tarikhi Abdullah Ibn Abud. Tt. Usul Mazhab Imam Ahmad. Beirut: Dar Sadir.

An-Nadwi, Ali Ahmad. 1991. al-2awa'id alFiqhiyyah Mafhuhuma Nasy'atuha, tatawwuruha, Dirasah Mu'allafatiha, Muhimmuha, Tatbiquha. Damaskus: Dar al-Qalam.

As-Sabiq, As-Sayyid. 1983. Fiqh Sunnah. Bandung: Alma'arif.

Departemen Agama Republik Indonesia, 1994. Al-Qur'an dan Terjemahannya. Edisi revisi., Semarang: Kumudasmoro Grafindo.

Esposito, John L. 2001. Ensiklopedi Dunia Islam Modern. Bandung: Mizan.

Emile, Durkheim. 2001. Hukum Islam di Negara Timur. Yogyakarta: Gama Media.

Gani, Abdullah Abdul. 1994. Pengantar Kompilasi Hukum Islam dalam Tata Hukum di Indonesia. Jakarta: Gema Insani Press.

Ghofur, Abdul. 2006. Hukum dan Praktik Perwakafan di Indonesia. Yogyakarta: Pilar Media.

Hooker, MB. 2003. Islam Mazhab Indonesia. Jakarta: Teraju.

Mahsun, Fuad. 2005. Hukum Islam Indonesia dari Nalar Partisipatoris hingga Emansipatoris. Yogyakarta: LKIS.

Mas'udi, Masdar F. 1995. "Meletakkan Kembali Maslahah Sebagai Acuan Syari'ah" Jurnal Ilmu dan Kebudayaan Ulumul al-Qur'an No. 3 Vol. VI.

Muslim, Ibn Al-Hujjaj. tt. Al-Jami' as-Sahih. Beirut: Dar al-Fikr. 
Mu'allim, Amir dan Yusdani. 2001. Konfigurasi Pemikiran Hukum Islam. Cet. Ke-2. Yogyakarta: UII Press.

Mughniyah, Muhammad Jawad. 2001. Fiqh Lima Mazhab. Jakarta: Lentera Basritama.

"Masjid Baiturrahman Kena Gusur Jama'ah Menuntut Dibangunkan Masjid Baru" Panji Masyarakat, No. 815 (10-2Sya'ban, 11-21 Januari, 1995.

"Membabat Kelapa Ala PLN di Poso" Panji Masyarakat No.774 Tahun XXXV JumadiAkhir, 21- 30 November, 1993.

Praja, Juhaya S. 1995. Perwakafan di Indonesia Sejarah Pemikiran Hukum dan Pembangunannya. Bandung: Yayasan Priara.

Qahaf, Mundzir. 2005. Manajemen Wakaf Produktif. Jakarta Timur: Khalifah.

Qudamah, Muhammad Ibn. 132 Kisah Taubat. Yogyakarta: Mitra Pustaka.

Rahman, Asymuni Abdul. 1976. Qaidahqaidah Fiqh. Jakarta: Bulan Bintang.

Rasjid, Sulaiman. 1992. Fiqh Islam. Bandung: Sinar Baru.

Rasydi, Lili. Filsafat Hukum dan Mazhab. Jakarta: Raja Grafindo Persada.

Rofiq, Ahmad. 2001. Hukum Islam di Indonesia. Yogyakarta: Gama Media.

Rafiq, Ahmad. 1998. Hukum Islam. Jakarta: Raja Grafindo.

Sa'adah, Mazro'atus. 2000. Relavansi Pendapat Ibn Taimiyyah tentang Perubahan dan
Penjuan Harta Benda Wakaf dengan Pasal 225 KHI. Yogyakarta: IAIN Sunan Kalijaga Press.

Shiddiqy, TM. Hasbi ash. 1995. Falasafah Hukum Islam. Jakarta: Bulan Bintang. 1997. Pokok-Pokok Pegangan Imamimam Mazhab dalam Membina Hukum Islam. Jakarta: Bulan Bintang.

1953. Dasar-dasar Fiqh Islam. Medan: Islamiyah.

Suhendi, Hendi. 2002. Fiqh Muamalah. Jakarta: Raja Grafindo Persada.

Syamsudin M. (ed). 1998. Hukum Adat dan Modernisasi Hukum. Yogyakarta: PT Fakultas Hukum UII.

Soekanto, Soejono. 1980. Pengantar Hukum di Indonesia. Jakarta: Rajawali.

Tim Redaksi Fokus Media. 2005. Himpunan Peraturan PerUndang-undangan Tentang Kompilasi Hukum Islam. Bandung: Fokus Media.

tt. al-Mughni fi al-Fiqh al-Mazhab Hambali. Riyad: Riyad alMaktabah al-Hadisah.

Usman, Suparman. 1997. Hukum Perwakafan di Indonesia. Cet. 1. Kudus: Dar 'Ulum Press.

Yanggo, Huzaemah Tahido. 1997. Pengantar Perbandingan Mazhab. Jakarta: Logos.

Zahrah, Muhammad Abu. 1997. Al-Muhadarat fī al-Waqfu. Mesir: Dar al-Fikr al'Ar 